\title{
Contact Dermatitis in Tertiary Hospital: A 2-year Retrospective Study
}

\author{
Efenina Ginting1, Damayanti², Deasy Fetarayani ${ }^{3}$, Afif Nurul Hidayati ${ }^{2,4}$ \\ ${ }^{1}$ Medical Program, Faculty of Medicine, Universitas Airlangga, Surabaya, Indonesia \\ ${ }^{2}$ Department of Dermatology and Venereology, Faculty of Medicine, Universitas Airlangga/Dr. \\ Soetomo General Academic Hospital Surabaya, Indonesia \\ ${ }^{3}$ Department of Internal Medicine, Faculty of Medicine, Universitas Airlangga/Dr. Soetomo General \\ Academic Hospital Surabaya, Indonesia \\ ${ }^{4}$ Universitas Airlangga Teaching Hospital, Surabaya, Indonesia
}

\begin{abstract}
Background: Contact dermatitis (CD) is a skin inflammatory caused by allergen or irritant that generates public health impact. $\mathrm{CD}$ is classified into two types, based on its etiological perspective, namely allergic contact dermatitis (ACD) due to a hypersensitivity type IV reaction and irritant contact dermatitis (ICD), which is a non-immunological reaction. Purpose: To determine the profile of CD patients at Dermatology and Venereology Outpatients Unit of Dr. Soetomo General Academic Hospital Surabaya in January 2018 - December 2019. Methods: A retrospective study by observation and recording data. The results of the data recap were then processed using Microsoft Excel to obtain conclusions. Result: The results obtained were ACD (61.9\%) and ICD (38.1\%), aged 26-45 years (32.7\%), female (79.3\%). The most frequent occupation was housewives (25.3\%), followed by private employees $(24.5 \%)$. The most suspected causative substance was cosmetic $(47.7 \%)$. The most common skin disease history was food allergy (11\%), followed by drug allergy (2.8\%), and atopic dermatitis (2.3\%). The most frequent manifestation was acute $(69.8 \%)$, with the most clinical presentation was erythematous macules $(35 \%)$. Most therapies were given in combination (73.6\%), with antihistamines $(61 \%)$ and topical corticosteroids $(49.2 \%)$ were the most prescription drug. Conclusion: ACD was more common than ICD, mostly in a female, dominated in the 26-45 years old. Housewife was the most occupational. Cosmetic was the most suspected causative substance. Food allergy was the most skin disease history. Acute was the most frequent manifestation. Erythematous macules were the most clinical presentation. Antihistamine and corticosteroid are the most common drug in combination therapy.
\end{abstract}

Keywords: Contact dermatitis, profile, public health.

Correspondence: Damayanti, Department of Dermatology and Venereology, Faculty of Medicine, Universitas Airlangga/Dr. Soetomo General Academic Hospital, Jl. Mayjen. Prof. Dr. Moestopo No. 6-8 Surabaya 60131, Telp. +62315501609, email: damayanti@fk.unair.ac.id.

\section{BACKGROUND}

Contact dermatitis is a skin disease due to contact with chemical substances. Contact dermatitis is one of the common skin diseases in the community due to daily activities in occupational settings. ${ }^{1}$ Skin disease reflects health conditions, and it is often underestimated or considered a harmless disease. However, it impacts both physically and psychologically and can significantly affect their quality of life. In addition, the accuracy, prompt diagnosis, and suitable treatment methods considerably affect the patient's recovery and prognosis.

The high prevalence of CD can be found in hair and make-up stylists, nurses, beauty clinics, food processing workers, and metal sector workers. ${ }^{2}$ In Indonesia, the prevalence of dermatitis is $6.78 \%$. An epidemiological study of CD in Indonesia shows that $97 \%$ of the 339 cases are contact dermatitis cases, with $66.3 \%$ being irritant contact dermatitis (ICD). ${ }^{3}$

A retrospective study specifically for ACD due to cosmetics from the Allergy-Immunology Division medical records in Dermatology and Venereology Outpatients Unit of Dr. Soetomo General Academic Hospital Surabaya from January 2014 to December 2017 revealed $289(26.1 \%)$ with contact dermatitis due to cosmetics from a total of 1105 contact dermatitis patients. The highest number of patients occurred in 2017,96 cases $(2.8 \%)$, and it has shown a significant increase since $2014 .^{4}$ This study evaluates the profile of contact dermatitis patients to obtain public health information regarding dermato-venereology diseases, especially contact dermatitis.

\section{METHODS}

This was a descriptive retrospective study of contact dermatitis patients at the Dermatology and Venereology Outpatient Unit of Dr. Soetomo General Academic Hospital Surabaya in January 2018 December 2019. The medical record was analyzed by considering the type of contact dermatitis, age, gender, 
history of skin disease, personal hygiene, activity/occupational, causative agents, clinical manifestations, and therapy. The obtained data were then processed using Microsoft Excel to obtain conclusions. This research has been reviewed and approved by Ethics Committee at Dr. Soetomo General Academic Hospital Surabaya (No.0126/LOE/ 301.4.2/IX/2020).

\section{RESULT}

We obtained 367 subjects, consisting of $227 \mathrm{ACD}$ (61.9\%) and 140 ICD (38.1\%) patients treated at the Dermatology and Venereology Outpatients Unit of Dr. Soetomo General Academic Hospital Surabaya period January 2018 - December 2019. The most age group in ACD patients was $19-25$ years (34\%) with 78 patients, while in ICD, it was $26-45$ years $(31.4 \%)$ with 44 patients. Therefore, most contact dermatitis patients were 26-45 years $(32.7 \%)$ in age. Most contact dermatitis patients were female, with 291 patients (79.3\%), while the remaining 76 patients $(20.7 \%)$ were males. There are two occupational groups with the most data collection, namely 44 housewives (31.4\%) in ICD and 58 private employees $(25.6 \%)$ in ACD. Thus, it can be seen that the group with the most work or activity in contact dermatitis patients is housewives with $93(25.3 \%)$ patients. The most suspected causative substance in ACD was cosmetics with 144 data $(57.6 \%)$, while in ICD were cleansers and cosmetics obtained the same amount with 51 (32.1\%) data. Thus, it can be concluded that cosmetics (47.7\%) are the most suspected materials causing contact dermatitis patients with ACD and ICD. The frequency distribution is presented in Table 1.

Table 1. The profile of CD patients at Dermatology and Venereology Outpatients Unit of Dr. Soetomo General Academic Hospital Surabaya period January 2018 - December 2019

$$
\text { ACD ICD Total ACD }
$$

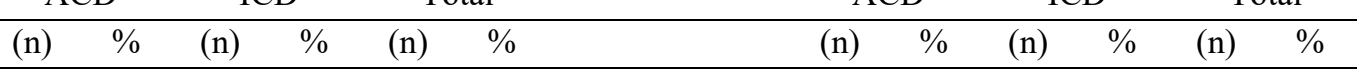

Contact

$\begin{array}{llllll}227 & 61.9 & 140 & 38.1 & 367 & 100\end{array}$

Occupation

Dermatitis

\begin{tabular}{|c|c|c|c|c|c|c|c|c|c|c|c|c|c|}
\hline \multicolumn{7}{|c|}{ Age } & \multirow{2}{*}{$\begin{array}{l}\text { Not in school } \\
\text { yet } \\
\text { Student }\end{array}$} & \multirow{2}{*}{$\begin{array}{c}0 \\
19\end{array}$} & \multirow{2}{*}{$\begin{array}{c}0 \\
8.4\end{array}$} & \multirow{2}{*}{$\begin{array}{l}0 \\
8\end{array}$} & \multirow{2}{*}{$\begin{array}{c}0 \\
5.7\end{array}$} & \multirow{2}{*}{$\begin{array}{c}0 \\
27\end{array}$} & \multirow{2}{*}{$\begin{array}{c}0 \\
7.4\end{array}$} \\
\hline$<10$ & 0 & 0 & 0 & 0 & 0 & 0 & & & & & & & \\
\hline $11-18$ & 25 & 11 & 14 & 10 & 39 & 1.6 & Undergraduate & 45 & 19.8 & 14 & 10 & 59 & 16.1 \\
\hline $19-25$ & 78 & 34 & 35 & 25 & 113 & 30.8 & Housewife & 49 & 21.6 & 44 & 31.4 & 93 & 25.3 \\
\hline $26-45$ & 76 & 33.4 & 44 & 31.4 & 120 & 32.7 & $\begin{array}{l}\text { Private } \\
\text { employees }\end{array}$ & 58 & 25.6 & 32 & 22.9 & 90 & 24.5 \\
\hline $46-60$ & 30 & 13 & 25 & 17.9 & 55 & 15 & Entrepreneur & 7 & 3 & 7 & 5 & 14 & 3.8 \\
\hline$>60$ & 18 & 7.9 & 22 & 15.7 & 40 & 10.9 & Civil Servant & 11 & 4.9 & 6 & 4.3 & 17 & 4.6 \\
\hline Total & 227 & 100 & 140 & 100 & 367 & 100 & Army/ Police & 1 & 0.4 & 0 & 0 & 1 & 0.3 \\
\hline \multicolumn{7}{|c|}{ Gender } & Unemployed & 6 & 2.6 & 4 & 2.9 & 10 & 2.7 \\
\hline Female & 183 & 80.6 & 108 & 77.1 & 291 & 79.3 & No data & 31 & 13,7 & 25 & 17.8 & 56 & 15.5 \\
\hline Male & 44 & 19.4 & 32 & 22.9 & 76 & 20.7 & Total & 227 & 100 & 140 & 100 & 367 & 100 \\
\hline Total & 227 & 100 & 140 & 100 & 367 & 100 & \multicolumn{7}{|c|}{ Suspected causative substance } \\
\hline \multicolumn{7}{|c|}{ History of skin disease } & Cleanser & 31 & 12.4 & 51 & 32.1 & 82 & 20 \\
\hline $\begin{array}{l}\text { Atopic } \\
\text { dermatitis }\end{array}$ & 4 & 1.6 & 5 & 3.4 & 9 & 2.3 & Clothing & 7 & 2.8 & 0 & 0 & 7 & 1.7 \\
\hline $\begin{array}{l}\text { Food } \\
\text { allergy }\end{array}$ & 31 & 12.7 & 12 & 8.2 & 43 & 11 & Cosmetic & 144 & 57.6 & 51 & 32.1 & 195 & 47.7 \\
\hline $\begin{array}{l}\text { Drug } \\
\text { allergy }\end{array}$ & 8 & 3.3 & 3 & 2.1 & 11 & 2.8 & Food & 11 & 4.4 & 4 & 2.5 & 15 & 3.7 \\
\hline No data & 202 & 82.4 & 126 & 86.3 & 328 & 83.9 & Topical drugs & 20 & 8 & 13 & 8.2 & 33 & 8 \\
\hline \multirow[t]{3}{*}{ Total } & 245 & 100 & 146 & 100 & 391 & 100 & Oil & 23 & 9.2 & 28 & 17.6 & 51 & 12.5 \\
\hline & & & & & & & Others & 14 & 5.6 & 12 & 7.5 & 26 & 6,4 \\
\hline & & & & & & & Total & 250 & 100 & 159 & 100 & 409 & 100 \\
\hline
\end{tabular}

Description: a patient might have contacted more than one suspected causative substance and may have more than one skin disease history

ACD: acute contact dermatitis; ICD: irritant contact dermatitis 
Table 2. Clinical presentation and manifestation distribution of CD patients at Dermatology and Venereology Outpatients Unit Of Dr. Soetomo General Academic Hospital Surabaya period January 2018 December 2019

\begin{tabular}{lcclcc}
\hline \multicolumn{1}{c}{ Clinical presentation } & Total & $\%$ & Clinical manifestation & Total & $\%$ \\
\hline Erythematous macules & 315 & 35 & Acute & 256 & 69.8 \\
\hline Papules & 157 & 17.5 & Chronic & 103 & 28 \\
\hline Pustule & 64 & 7 & No data available & 2.2 \\
\hline Vesicle & 13 & 1.5 & & & \\
\hline Crusts & 13 & 1.5 & & & \\
\hline Erosion & 64 & 7 & & & \\
\hline Excoriation & 16 & 1.8 & & \\
\hline Lichenification & 29 & 3.2 & & \\
\hline Xerosis & 88 & 9.8 & & & \\
\hline Ichthyosis & 4 & 0.5 & & & 100 \\
\hline Fissure & 19 & 2.1 & & \\
\hline Scales & 95 & 10.6 & & \\
\hline Others & 22 & 2.5 & & \\
\hline Total & 899 & 100 & & \\
\hline Note: & & & & \\
\hline
\end{tabular}

Note: one patient may experience more than one clinical presentation

Table 3. Therapy distribution for CD patients at Dermatology and Venereology Outpatients Unit of Dr. Soetomo General Hospital Academic Surabaya period January 2018 - December 2019

\begin{tabular}{lcc}
\hline \multicolumn{1}{c}{ Therapy } & Total & Percentage (\%) \\
\hline Systemic & 50 & 13.6 \\
Topical & 42 & 11.4 \\
Systemic and topical & 270 & 73.6 \\
No data available & 5 & 1.4 \\
\hline Total & 367 & 100 \\
\hline
\end{tabular}

Table 4. Systemic and topical drug distribution for CD patients at Dermatology and Venereology Outpatients Unit of Dr. Soetomo General Hospital Academic Surabaya period January 2018 - December 2019

\begin{tabular}{|c|c|c|c|c|c|}
\hline Drug classes & Data & $\%$ & Drug names & Data & $\%$ \\
\hline \multicolumn{6}{|l|}{ Systemic drug distribution } \\
\hline \multirow[t]{3}{*}{ Antihistamines } & 300 & 61 & Cetirizine & 268 & 54.5 \\
\hline & & & Loratadine & 32 & 6.5 \\
\hline & & & Hydroxizine & 0 & 35.8 \\
\hline \multirow[t]{2}{*}{ Corticosteroids } & 176 & 35.7 & Prednisone & 0 & 0.8 \\
\hline & & & Dexamethasone & 176 & 1.4 \\
\hline \multirow[t]{3}{*}{ Antibiotics } & 15 & 3.1 & Amoxicillin & 4 & 0.8 \\
\hline & & & Erythromycin & 7 & 1.4 \\
\hline & & & Cloxacillin & 4 & 0.8 \\
\hline Others & 1 & 0.2 & Paracetamol & 1 & 0.2 \\
\hline Total & 492 & 100 & & 492 & 100 \\
\hline \multicolumn{6}{|l|}{ Topical drug distribution } \\
\hline Antihistamines & 0 & 0 & & 0 & 0 \\
\hline \multirow{3}{*}{ Corticosteroids } & 207 & 49.2 & Desoxymethasone & 45 & 10.7 \\
\hline & & & Hydrocortisone & 86 & 20.4 \\
\hline & & & Mometasone furoate & 76 & 18 \\
\hline \multirow[t]{2}{*}{ Antibiotics } & 37 & 8.8 & Sodium fusidate & 36 & 8.6 \\
\hline & & & Gentamicin cream & 1 & 0.2 \\
\hline \multirow[t]{6}{*}{ Moisturizer } & 173 & 41.1 & Biocream $\AA$ & 40 & 9.5 \\
\hline & & & Vaseline album & 56 & 13.3 \\
\hline & & & Urea & 20 & 5 \\
\hline & & & Nutricream ${ }^{\circledR}$ & 30 & 7 \\
\hline & & & Atopiclair $\mathbb{R}$ & 10 & 2.4 \\
\hline & & & Sunblock & 17 & 4 \\
\hline Natrium chloride compress & 1 & 0.2 & Natrium chloride solution & 1 & 0.2 \\
\hline Others & 1 & 0.7 & Salicyl powder & 3 & 0.7 \\
\hline Total & 421 & 100 & & 421 & 100 \\
\hline
\end{tabular}

Note: one patient can receive more than one drug 
Based on Table 1, the highest number of history of skin disease in contact dermatitis patients was 43 (11\%) food allergy, followed by $11(2.8 \%)$ drug allergy, $9(2.3 \%)$ atopic dermatitis, and no available data in $328(83.9 \%)$ patients. Food allergy was the most common skin disease history in ACD with 31 (12.7\%) patients and ICD with $12(8.2 \%)$ patients.

Most clinical manifestation was acute, with 256 patients $(69.8 \%)$. Meanwhile, the most clinical presentation was erythematous macules (35\%) with 315 patients.

The therapy distribution is divided into systemic, topical, and combination of systemic and topical treatment. There were $50(13.6 \%)$ systemic therapies, $42(11.4 \%)$ topical therapies, $270(73.6 \%)$ combined therapies, and $5(1.4 \%)$ unspecified therapies. In systemic therapy, the most drug were $300(61 \%)$ antihistamines, with $268(54.5 \%)$ cetirizine drugs. In topical therapy, the most drug class was 207 (49.2\%) corticosteroids, with $86(20.4 \%)$ hydrocortisone cream.

\section{DISCUSSION}

This study recorded a total of 367 outpatients, 227 (61.9\%) of them were ACD patients, and 140 (38.1\%) were ICD patients. In age distribution, most of the patients were $26-45$ years old $(32.7 \%)$, followed by 19 25 years old $(30.8 \%)$. Naturally, this group is prone to experiencing $\mathrm{ACD} / \mathrm{ICD}$ due to occupational. Indrawan et al. reported that workers dominated by those aged 31-40 years are more at risk of experiencing CD. ${ }^{5}$ Furthermore, that result is in accordance with this study that shows productive age is prone to experiencing $\mathrm{ACD} / \mathrm{ICD}$ due to occupational setting and greater change for dermatitis-causative substance due to higher mobility. However, the result of this study are not in line with the theoretical concept argued by Zahruddin and Damayanti. They stated that older persons are more at risk of experiencing dermatitis due to collagen degradation and making skin drier. ${ }^{6}$

We found the most CD patients were females, with $291(79.3 \%)$ cases. Sunaryo et al. also reported that $52(67.5 \%)$ of $77 \mathrm{CD}$ patients were females. ${ }^{7}$ Female skin produces less oil to protect and maintain skin moisture. Meanwhile, getting older makes the skin thinner due to collagen degradation, making it more prone to dermatitis. ${ }^{5,8}$ This shows that woman are more at risk than men. ${ }^{9}$

Most occupation in this study were housewives with 93 patients $(25.3 \%)$, followed by private employees with 90 patients $(24.5 \%)$. Their work activities tend to expose them to allergens and irritants. Also, Sunaryo et al. reported similar results that out of 77 patients, 19 patients $(24.7 \%)$ were housewives. ${ }^{7}$
The most suspected causative substances were 195 cosmetics (47.7\%) and 82 cleaners (20\%). This is in accordance with the research of Noviandini and Prakoeswa. They reported that 18 of 27 patients (66.7\%) presented positive results for a cosmetic patch test. ${ }^{10}$ Cosmetics is the most common cause because most patients were women aged 26-45 years who had high mobility and frequently wear cosmetics. Apart from cosmetics, cleanser products can also cause CD, especially ICD. Repeated and extended cleanser use can cause dry skin due to lipid erosion, increasing transepidermal water loss, losing its skin barrier function, and making it prone to irritation. ${ }^{11}$

We found that 43 (11\%) of 367 patients had food allergies. We found different results from the concept of risk factors for dermatitis. The leading risk factor for ICD is atopic. ${ }^{12}$ Patients with a history of atopic have a low threshold and skin barrier function, so they have more severe reactions with susceptibility to irritation. However, another study by Fonacier et al. said that atopic dermatitis is not the leading risk factor for developing CD. ${ }^{13}$ Similar result has been reported by Afifah. She reported no difference in the proportion of contact dermatitis in patients with or without a history of allergy. ${ }^{14}$

Acute $256(69.8 \%)$ was the most clinical manifestation, and erythematous macules 315 (35\%) was the most frequent clinical presentation in this study result. This results are in accordance with the Indonesian Society of Dermatology and Venereology (PERDOSKI), which states that in ACD, acute lesions are characterized by erythematous macules. ${ }^{15}$ Likewise, the literature Novak et al. also said that the presence of erythematous macules characterized acute ICD. ${ }^{16}$ Similar results were also obtained in Rubianti and Prakoeswa's study of 289 patients, 256 patients with erythematous macular efflorescence. ${ }^{4}$

Combined therapy was the most common therapy received by patients, as observed in 270 cases $(73.6 \%)$. In systemic therapy, 300 (61\%) antihistamines was the most common drug class, with 268 (54.5\%) cetirizine was the most drug. Meanwhile, in topical therapy, 207 (49.2\%) corticosteroids were the most drug class, with $86(20.4 \%)$ hydrocortisone cream as the most prescribed drug. Antihistamines administration aims to reduce itching, while topical corticosteroids is generally applied to local and limited lesions to reduce the inflammation. ${ }^{17,18}$ Also, Sunaryo et al. reported similar results that from 77 patients, 33 (42.8\%) patients received antihistamine and corticosteroid therapy. ${ }^{7}$ Witasari and Sukanto also reported 43 (86\%) antihistamines and $31(62 \%)$ topical corticosteroids prescriptions. $^{17}$ 
The study result are valid for CD patients in the Dermatology and Venereology Outpatients Unit of Dr. Soetomo General Academic Hospital Surabaya in January 2018 - December 2019. They cannot be generalized as a condition, especially in $\mathrm{CD}$ patient profile in general. The diagnosis criteria and etiology are only obtained based on medical records, thus limiting complete and detailed observation.

Understanding health information related to contact dermatitis and hygiene can improve patients' health quality as well as preventing CD. Therefore, we suggest future research to explore limiting factors in this study that can influence the incidence of CD.

\section{REFERENCES}

1. Djuanda A. Ilmu Penyakit Kulit dan Kelamin. 4th ed. Jakarta: Balai Penerbit FKUI; 2011; 2.

2. Sartika F, Septiawati D. Faktor-faktor yang mempengaruhi keluhan dermatitis kontak iritan pada pekerja konstruksi Citra Grand City Palembang [Skripsi]. Palembang: Fakultas Kesehatan Masyarakat Universitas Sriwijaya; 2019.

3. Putri FY, Suwonda A, Widjasena B. Hubungan paparan debu kayu dengan kejadian dermatitis kontak iritan pada pekerja mebel PT. X Jepara. Jurnal Kesehatan Masyarakat 2016;4(4):652-58.

4. Rubianti MA, Prakoeswa CRS. Profile of allergic contact dermatitis patients due to cosmetic. Berkala Ilmu Kesehatan Kulit dan Kelamin. 2019;31(1):35-40.

5. Indrawan IA, Suwondo A, Lestantyo D. Faktorfaktor yang berhubungan dengan kejadian dermatitis kontak iritan pada pekerja bagian premix Di PT. X Cirebon. Jurnal Kesehatan Masyarakat 2014:2(2):110-18.

6. Zahruddin A, Damayanti D. Skin aging: pathophysiology and clinical manifestation. Berkala Ilmu Dermatology and Venereology. 2018;30(3):208-15.

7. Sunaryo Y, Pandaleke HE, Kapantow MG. Profil dermatitis kontak di Poliklinik Kulit dan Kelamin RSUP Prof Dr. RD Kandou Manado Periode Januari-Desember 2012. e-CliniC 2014;2(1).

8. Marwah A. Faktor-faktor yang berhubungan dengan gejala dermatitis kontak pada pekerja harian lepas di PT. Indojaya Agrinusa Medan Unit Poultryfeed tahun 2018 [Skripsi]. Medan: Fakultas Kesehatan Masyarakat Universitas Sumatera Utara; 2018.
9. Daulay RA. Faktor-faktor yang berhubungan dengan terjadinya dermatitis kontak pada pekerja di pabrik tahu Desa Suka Maju Binjai tahun 2016 [Tesis]. Medan: Fakultas Kesehatan Mayarakat Universitas Sumatera Utara; 2016.

10. Noviandini A, Prakoeswa CRS. Patch test profile of contact dermatitis patients. Berkala Ilmu Kesehatan Kulit dan Kelamin. 2014;26(2):1-7.

11. Chairunnisa I, Wijayadi LJ, Nataprawira SMD. Gambaran kadar hidrasi kulit dan kejadian dermatitis kontak iritan pada petugas kebersihan di Universitas Tarumanagara. Jurnal Bakti Masyarakat Indonesia 2020;3(1):29-36.

12. Kementerian Kesehatan Republik Indonesia. Peraturan Menteri Kesehatan Republik Indonesia Nomor 5 Tahun 2014 tentang Panduan Praktik Klinis Bagi Dokter di Fasilitas Pelayanan Kesehatan Primer. Jakarta: Kementerian Kesehatan RI; 2014.

13. Fonacier L, Bernstein DI, Pacheco K, Holness DL, Blessing-Moore J, Khan D, et al. Contact dermatitis: a practice parameter-update 2015. The Journal of Allergy and Clinical Immunology: In Practice 2015;3(3):S1-39.

14. Afifah N. Faktor-faktor yang berhubungan dengan kejadian dermatitis kontak pada pekerja proses finishing meubel kayu di Wilayah Ciputat Timur tahun 2012 [Skripsi]. Jakarta: Fakultas Kedokteran dan Ilmu Kesehatan Universitas Islam Negeri Syarif Hidayatullah; 2012.

15. Perhimpunan Dokter Spesialis Kulit dan Kelamin Indonesia (PERDOSKI). Panduan Praktik Klinik Bagi Dokter Spesialis Kulit Dan Kelamin Di Indonesia. Jakarta: Grand Salemba; 2017.

16. Novak-Bilić G, Vučić M, Japundžić I, MeštrovićŠtefeko J, Stanić-Duktaj S, Lugović-Mihić L. Irritant and allergic contact dermatitis-skin lesion characteristics. Acta Clinica Croatia 2018;57 (4):713-19.

17. Witasari D, Sukanto H Occupational contact dermatitis: retrospective study. Berkala Ilmu Kesehatan Kulit dan Kelamin - Periodical of Dermatology and Venereology. 2012;26(6):16167.

18. Litchman G, Nair PA, Atwater AR, Bhutta BS. Contact dermatitis [Internet]. StatPearls. 2021 [cited 8 July 2021]. Available from: https://www.ncbi.nlm.nih.gov/books/NBK45923 0/ 